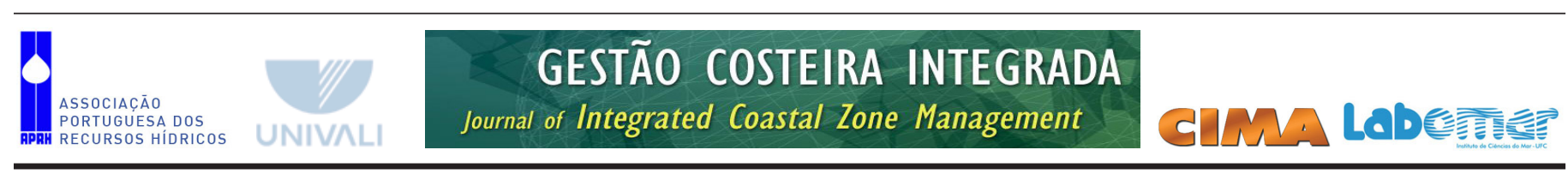

http://www.aprh.pt/rgci/pdf/rgci-467_Fattorini.pdf | DOI:10.5894/rgci467

\title{
Assessing small island prioritisation using species rarity: the tenebrionid beetles of Italy *
}

\author{
Avaliação de Prioridades de Conservação em pequenas ilhas, usando a raridade de \\ espécies: os escaravelhos tenebriónidos de Itália **
}

\author{
Simone Fattorini ${ }^{\circledR, 1}$, Leonardo Dapporto ${ }^{2}$
}

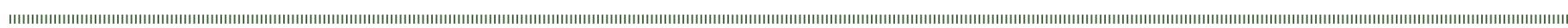

\begin{abstract}
We investigated conservation priorities of Italian small islands on the basis of tenebrionid species (Coleoptera Tenebrionidae) which are insects typically associated with coastal environments. Firstly, we estimated vulnerability of tenebrionid island communities in four different ways using their inter-island distribution, their overall rarity, their biogeographical characterization and the coastal perimeter of the occupied islands. Then, these four sets of vulnerability values were used to rank biotopes using the Biodiversity Conservation Concern index, BCC, which reflects the average rarity score of the species present in a site, and the Biodiversity Conservation Weight index, BCW, which reflects the sum of rarity scores of the same species assemblage. We found that most of the studied islands have been recovered as having some conservation value, but the Tuscan Islands, Ustica, Pantelleria and the Pelagie Islands were found to have highest priority.
\end{abstract}

Keywords: Conservation Planning; Insects; Island Biogeography; Italy; Mediterranean.

\section{RESUMO}

Neste artigo, a Investigação centra-se nas prioridades de Conservação em pequenas ilhas em Itália, com base em estudos de espécies Tenebrionidae (Coleoptera Tenebrionidae), insetos usualmente associados a ambientes costeiros. Em primeiro lugar, estimou se a vulnerabilidade das comunidades Tenebrionidae insulares de quatro formas diferentes: usando a sua distribuição inter-ilha; a sua raridade total; a caracterização biogeográfica; e o perimetro costeiro das ilhas ocupadas. Seguidamente, estas quatros conjuntos de dados de vulnerabilidade, foram usados para ordenar os biótopos de acordo com o Biodiversity Conservation Concern index, BCC, que reflete a raridade média das espécies presentes num sitio e o Biodiversity Conservation Weight index, $B C W$, que reflete a soma dos valores de raridade para algumas espécies da composição. Conclui-se que muitos estudos em pequenas ilhas são recuperados como tendo algum valor de conservação, mas as ilhas Tuscanas, Ustica, Pantelleria e Pelagie apresentam os mais altos valores de prioridade.

Palavras-Chave: Planeamento e Conservação; Insetos; Biogeografia Insular; Itália; Mediterrâneo.

@ - Corresponding author: simone_fattorini@virgilio.it

1 - Azorean Biodiversity Group (GBA, CITA-A) and Platform for Enhancing Ecological Research \& Sustainability (PEERS), Departamento de Ciências Agrárias, Universidade dos Açores, Rua Capitão João d'Ávila, Pico da Urze, 9700-042, Angra do Heroísmo, Terceira, Azores, Portugal.

2 - Centre for Ecology, Environment and Conservation, Department of Biological and Medical Sciences, Faculty of Health and Life Sciences, Oxford Brookes University, Oxford, OX3 OBP, UK.

* Submission: 30 December 2013; Evaluation: 5 February 2014; Reception of revised manuscript. 11 February 2014; Accepted: 13 February 2014; Available on-line: 19 February 2014

** Portuguese Title, Abstract and captions by Helena Calado on behalf of the Journal Editorial Board 


\section{INTRODUCTION}

The Mediterranean basin is occupied by almost 12,000 islands and islets (Arnold, 2008). Most of the Mediterranean islands have an area less than $3 \mathrm{~km}^{2}$; only 162 Mediterranean islands are more than $10 \mathrm{~km}^{2}$ large, 15 have an area over $500 \mathrm{~km}^{2}$, and 9 present an area over $1000 \mathrm{~km}^{2}$ (Morey \& Martinez, 2000).

Because of the high "perimeter/area" ratio that characterizes small islands, their environmental diversity tends to be mostly represented by coastal ecosystems. Thus, although small islands occupy only a very small fraction of Earth surface, they may play an important role in conserving coastal ecosystems. Usually, the smaller the island, the higher the proportion of coastal valued and/or threatened ecosystems (Morey \& Martinez, 2000). The total area of the Mediterranean islands is about $13 \%$ of the sea area, but they have a coastal length of $24,622 \mathrm{~km}$, only $15 \%$ less than the mainland coastline.

In an attempt to achieve sustainability of Mediterranean coastal areas, fourteen Contracting Parties of the Barcelona Convention signed the Integrated Costal Zone Management Protocol in 2008, thus recognizing the need for management policies that are based on a holistic viewpoint of the functions that makeup the complex and dynamic nature of interactions in the coastal environment. This Protocol was then ratified by the European Union in 2010. In 2002, the European Parliament and the European Council also adopted a Recommendation on Integrated Coastal Zone Management which stressed the need to cover "the full cycle of information collection, planning, decision-making, management and monitoring of implementation" (http:// ec.europa.eu/environment/iczm/home.htm).

As small islands are largely coastal entities of reduced surface, they are areas where the problems of sustainability are exacerbated (see, for example, Saffache \& Angelelli, 2010, for a discussion on the Lesser Antilles case) and present therefore the need for a urgent rethinking about their management (Dias et al., 2010). Coastal ecosystems in small islands can be threatened by a number of reasons, including pollution, coastal land occupation by tourist installations, concrete structures and networks of roads, population increase and increase in tourist pressure, resulting in a general landscape degradation and biodiversity loss (Morey \& Martinez, 2000). Rising in sea level due to global warming is another important threat for coastal habitats of small islands (see Manne 2013 for a general discussion). With their environment more fragile and vulnerable than that of continental sites of similar areas, Mediterranean small islands should be therefore considered as valued threatened lands, needing special protection (Morey \& Martinez, 2000). In terms of biodiversity, small islands host exclusive assortments of species, sometimes including endemic taxa, usually represented by small populations, which enhance their conservation value (Fattorini, 2006a; Whittaker \& Fernández-Palacios 2007). Thus, for an integrated management of islands it is essential to know where biodiversity is concentrated and where it is most imperilled, in order to prioritise conservation actions and adopt the most urgent decisions.
The distribution of small islands in the western and eastern sectors of the Mediterranean Basin is uneven. In the Western Mediterranean there are some large islands (the Balearics, Corsica, Sardinia, Sicily) with relatively few small islands (usually associated with the largest ones), whereas in the Eastern Mediterranean there are few large islands but an extraordinary large number of small islands, especially in the Adriatic Sea (near the coast of the former Yugoslavia) and in the Aegean Sea. Placed in the centre of the Mediterranean, the Italian peninsula is at the interface between the Western and the Eastern sectors. Thus, some Italian small islands are placed in the Western Mediterranean, a few other in the Eastern Mediterranean. Moreover, Italian small islands vary greatly in their isolation (distance from the mainland and/ or other islands) and geographical position with respect to major island systems and mainland areas which might act as source of species: for example, some islands are closer to the Sardinia-Corsican area and North African coasts than to the Italian peninsular ones. Thus, although not so numerous as those forming the Greek archipelagos, the Italian islands represent a biogeographically very heterogeneous assemblage of areas in most cases under strong human pressure.

Our knowledge of the biodiversity of Italian small islands varies considerably among islands and taxa, so only for the best investigated taxa (such as butterflies, Dennis et al., 2008) and archipelagos (such as the Tuscan Islands or the circumSicilian islands. Fattorini, 2009a, 2010a) wide comparisons and cross-taxon biogeographical and conservation analyses are possible. Among the best sampled taxa for which there are a large number of well explored islands, the beetles belonging to the family Tenebrionidae are particularly interesting for the conservation of coastal ecosystems because they represent a conspicuous component of the beetle fauna inhabiting Mediterranean coastal ecosystems in terms of species richness, individual abundance and biomass (Fattorini, 2008a; Fattorini et al., 2012a and references therein).

Taking advantage of a series of previous researches (Fattorini, 2006a, 2008a, 2009a,b, 2011a; Fattorini \& Fowles, 2005) we were able to obtain virtually complete tenebrionid species lists for most of the Italian small islands and to use these data in the present paper to investigate conservation priorities. For this, we evaluated tenebrionid species vulnerability and used this information to identify the islands that host the most imperilled tenebrionid communities.

\section{MATERIAL AND METHODS}

We collected presence data on tenebrionid species for 57 Italian small islands (Figure 1). These data were obtained from literature sources (reviewed in Fattorini, 2008, plus data provided in Fattorini, 2009a,b, 2010a, 2011a,b) and personal new records.

Study islands varied greatly for their size and distance from the mainland. Island geographical characteristics are given in Table 1 whereas their conservation status is given in Table 2. Island area varied from $0.0000249 \mathrm{~km}^{2}$ (a very small islet in the Tuscan Archipelago) to $223.5 \mathrm{~km}^{2}$ (Elba Island) (mean \pm SD: $12.185 \pm 32.669$ ). Distance to the mainland varied from $0 \mathrm{~km}$ (Mount Argentario, a fossil island currently connected to the mainland by three narrow strips of land) to 


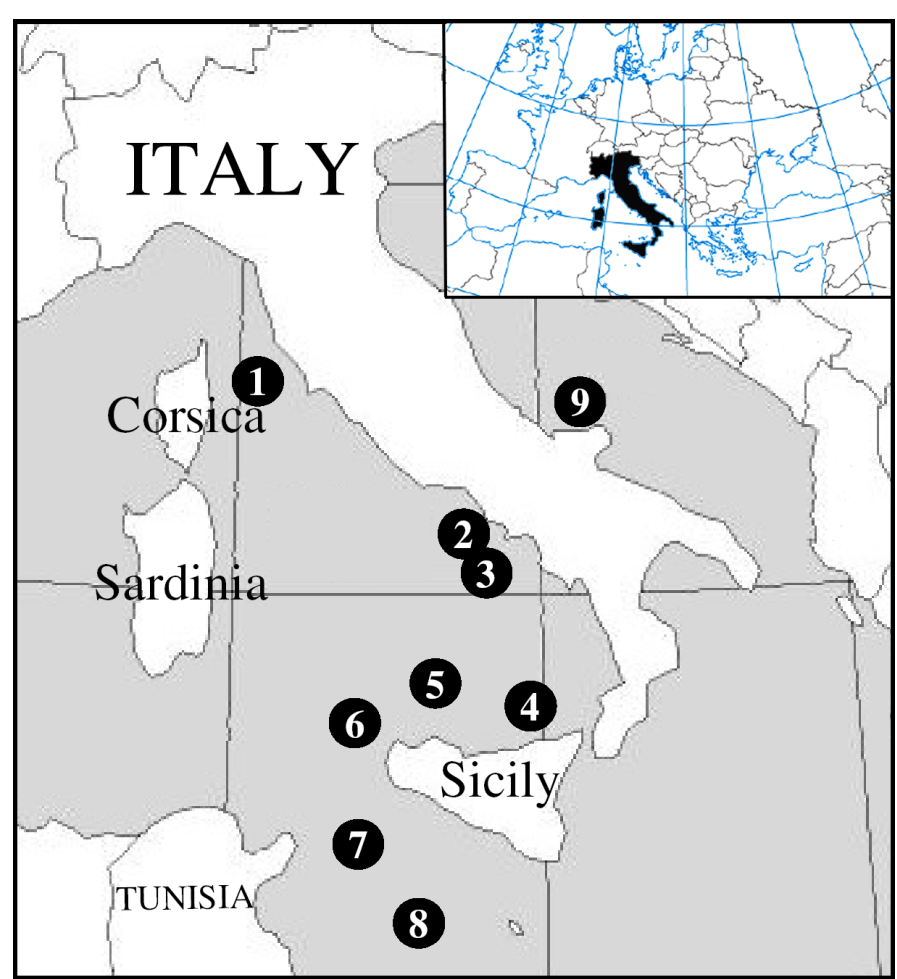

Figure 1. Location of studied Italian islands. 1: Tuscan Archipelago; 2: Pontine Islands; 3: Campane Islands, 4: Aeolian Islands; 5: Ustica Island; 6: Aegadian (Egadi) Islands; 7: Pantelleria Island; 8: Pelagian (Pelagie) Islands; 9: Tremiti Islands. The inset shows the position of Italy (in black) within the Mediterranean basin.

Figura 1. Localização das ilhas italianas estudadas. 1 Arquipélago Toscano, 2. Ilhas Pontinas; 3: Ilhas Campânia, 4: Ilhas Eólias; Ilhas Ustica, 6: Ilhas Egadi, Ilhas Pantelleria, 8: Ilhas Pelagie, 9: Ilhas Tremiti. Assinalado a negro a posição de Itália na Bacia Mediterrânea.

$162 \mathrm{~km}$ (Linosa, close to North African coasts) (mean \pm SD: $34.307 \pm 29.886$ ). Island maximum elevation, which may be considered an indirect measure of habitat diversity, varied from $0 \mathrm{~m}$ (for certain very small islands) to $1019 \mathrm{~m}$ (Elba island) (mean \pm SD: $252.140 \pm 290.918$ ).

We considered presence data for 139 native tenebrionid species. Taxonomy followed Löbl \& Smetana (2008). Cosmopolitan species, such as Alphitophagus bifasciatus, Gnathocerus cornutus, Latheticus oryzae, Tribolium castaneum, Tribolium confusum, Tenebrio molitor, Tenebrio obscurus, and Alphitobius diaperinus, which are associated with stored food, were not considered.

Islands were ranked on the basis of the vulnerability of their tenebrionid communities using the Biodiversity Conservation Concern (BCC) index (Fattorini, 2006b) and the Biodiversity Conservation Weight (BCW) index (Fattorini et al., 2012b). In the BCC index, species occurring in a given area are classified into categories of endangerment and weighted by the respective vulnerability. The BCC index also combines the vulnerability of each species with total richness to obtain a measure of relative conservation.

$$
\mathrm{BCC}=\frac{\sum_{i=1}^{L}\left(\alpha_{i}-\alpha_{\min }\right)}{L\left(\alpha_{\max }-\alpha_{\min }\right)}
$$

The BCC is calculated as:

where $L$ is the local (island) species richness, $\alpha_{i}$ is the weight assigned to the $i$ th category of vulnerability, $\alpha_{\text {min }}$ is the minimum weight among all species; and $\alpha_{\max }$ is maximum weight among all species. This formulation ensures the index ranges from 0 (all species belonging to the lower conservation category, $\alpha_{1}=1$ ) to 1 (all species belonging to the highest endangerment category, $\alpha_{\max }$ ). The BCC index has been previously applied to identify priority areas or biotopes for butterflies in Mediterranean islands and European countries (Fattorini, 2006, 2009b; Dapporto \& Dennis, 2008), fish in France (Bergerot et al., 2008; Laffaille et al., 2011; Maire et al., 2013), tenebrionids, butterflies, birds and mammals in the Central Apennines (Fattorini, 2010b, c), and arthropods in Azorean forest fragments (Fattorini et al., 2012b).

The BCC index is a 'relative measure', which means that it is not sensitive to species richness. This may be an advantage to compare species assemblages with different species richness, but poses some problems. For example, an assemblage with a single species, having this species $\alpha_{\text {max }}$, would receive the same score as an assemblage with 10 species, all with $\alpha_{\max }$. Or worse, an assemblage with a single species with $\alpha_{\max }$ has a higher score than an assemblage with 10 species, 9 with $\alpha_{\max }$ and one with $\alpha_{\mathrm{i}}<\alpha_{\max }$. To overcome this problem, Fattorini et al. (2012b) introduced the BCW, which is calculated as follows:

$$
\mathrm{BCW}=\frac{\sum_{i=1}^{L}\left(\alpha_{i}-\alpha_{\min }\right)}{\sum_{i=1}^{S}\left(\alpha_{i}-\alpha_{\min }\right)}
$$

where $S$ is the total species richness for all sites (all other symbols as for BCC, see above).

To express species vulnerability, we used four different approaches. In a first approach, we weighted species as an inverse function of their distribution. As the most widespread species occurred on 29 islands, species weights were calculated as the number of inhabited islands divided by 29 . Using this weighting scheme in the BCC calculation, the most widespread species received an $\alpha$-value of 1 , whereas species occurring in only one island received an $\alpha$-value of 29. The BCC calculated using this scheme will be referred to as BCC1.

In a second approach, we weighted species using the Kattan index (Kattan, 1992), which is based on species geographical distribution (wide/narrow distribution), habitat specificity (broad/restricted habitat specificity) and abundance (abundant/scarce population) and has been previously used to express species rarity in tenebrionid assemblages (Fattorini, 2008b, 2010b, c, 2013a, b). These 
Table 1. Geographical characteristics of the Italian small islands.

Tabela 1. Caracteristicas geográficas das pequenas ilhas italianas

\begin{tabular}{|c|c|c|c|c|c|c|c|}
\hline Archipelago & Island & Latitude & Longitude & Area $\left(\mathbf{k m}^{2}\right)$ & $\begin{array}{l}\text { Maximum } \\
\text { elevation (m) }\end{array}$ & Perimeter $(\mathbf{k m})$ & $\begin{array}{l}\text { Distance to the } \\
\text { mainland }(\mathbf{k m})\end{array}$ \\
\hline Aegadian & Favignana & $37^{\circ} 55^{\prime} 34^{\prime \prime}$ & $12^{\circ} 19^{\prime} 16^{\prime \prime}$ & 19.7 & 302 & 33 & 5.78 \\
\hline Aegadian & Levanzo & $37^{\circ} 59^{\prime} 59^{\prime \prime}$ & $12^{\circ} 20^{\prime} 04^{\prime \prime}$ & 5.61 & 278 & 15 & 12.39 \\
\hline Aegadian & Marettimo & $37^{\circ} 58^{\prime} 20^{\prime \prime}$ & $12^{\circ} 03^{\prime} 20^{\prime \prime}$ & 12.06 & 686 & 18 & 30.34 \\
\hline Aeolian & Alicudi & $38^{\circ} 32^{\prime} 38^{\prime \prime}$ & $14^{\circ} 21^{\prime} 12^{\prime \prime}$ & 5.1 & 675 & 8 & 53.13 \\
\hline Aeolian & Basiluzzo & $38^{\circ} 39^{\prime} 48^{\prime \prime}$ & $15^{\circ} 06^{\prime} 50^{\prime \prime}$ & 0.29 & 165 & 3.3 & 43.5 \\
\hline Aeolian & Bottaro & $38^{\circ} 38^{\prime} 16^{\prime \prime}$ & $15^{\circ} 06^{\prime} 37^{\prime \prime}$ & 0.0073 & 21 & 0.44 & 42 \\
\hline Aeolian & Filicudi & $38^{\circ} 34^{\prime} 17^{\prime \prime}$ & $14^{\circ} 33^{\prime} 45^{\prime \prime}$ & 9.49 & 774 & 14.5 & 45.3 \\
\hline Aeolian & Lipari & $38^{\circ} 29^{\prime} 11^{\prime \prime}$ & $14^{\circ} 56^{\prime} 3^{\prime \prime}$ & 37.29 & 602 & 33 & 27.78 \\
\hline Aeolian & Lisca Bianca & $38^{\circ} 38^{\prime} 22^{\prime \prime}$ & $15^{\circ} 06^{\prime} 51^{\prime \prime}$ & 0.0413 & 30 & 0.81 & 42 \\
\hline Aeolian & Panarea & $38^{\circ} 38^{\prime} 14^{\prime \prime}$ & $15^{\circ} 04^{\prime} 02^{\prime \prime}$ & 3.34 & 421 & 8.5 & 42 \\
\hline Aeolian & Pietra del Bagno & $38^{\circ} 28^{\prime} 29^{\prime \prime}$ & $14^{\circ} 53^{\prime} 45^{\prime \prime}$ & 0.0021 & 21 & 0.2 & 28 \\
\hline Aeolian & Salina & $38^{\circ} 33^{\prime} 49^{\prime \prime}$ & $14^{\circ} 50^{\prime} 16^{\prime \prime}$ & 26.38 & 962 & 24 & 38.2 \\
\hline Aeolian & Scoglio Faraglione & $38^{\circ} 34^{\prime} 46^{\prime \prime}$ & $14^{\circ} 48^{\prime} 02^{\prime \prime}$ & 0.0049 & 35 & 0.43 & 39 \\
\hline Aeolian & Stromboli & $38^{\circ} 47^{\prime} 38^{\prime \prime}$ & $15^{\circ} 12^{\prime} 40^{\prime \prime}$ & 12.19 & 926 & 14.5 & 55.55 \\
\hline Aeolian & Strombolicchio & $38^{\circ} 49^{\prime} 02^{\prime \prime}$ & $15^{\circ} 15^{\prime} 07^{\prime \prime}$ & 0.003 & 49 & 0.3 & 46.5 \\
\hline Aeolian & Vulcano & $38^{\circ} 24^{\prime}$ & $14^{\circ} 58^{\prime}$ & 20.87 & 500 & 26.5 & 20.6 \\
\hline Campane & Capri & $40^{\circ} 33^{\prime} 3.2^{\prime \prime}$ & $14^{\circ} 14^{\prime} 33.36$ & 10.4 & 585 & 17 & 5 \\
\hline Campane & Ischia & $40^{\circ} 43^{\prime} 40^{\prime \prime}$ & $13^{\circ} 54^{\prime} 40^{\prime \prime}$ & 46.3 & 789 & 34 & 9.37 \\
\hline Campane & Vivara & $40^{\circ} 44^{\prime} 37^{\prime \prime}$ & $13^{\circ} 59^{\prime} 37^{\prime \prime}$ & 0.3563 & 110 & 3 & 6.19 \\
\hline Pelagian & Lampedusa & $35^{\circ} 30^{\prime} 56^{\prime \prime}$ & $12^{\circ} 34^{\prime} 23^{\prime \prime}$ & 20.2 & 133 & 26 & 120 \\
\hline Pelagian & Lampione & $35^{\circ} 33^{\prime} 16^{\prime \prime}$ & $12^{\circ} 19^{\prime} 59^{\prime \prime}$ & 0.025 & 40 & 1.8 & 130 \\
\hline Pelagian & Linosa & $35^{\circ} 52^{\prime}$ & $12^{\circ} 52^{\prime}$ & 5.34 & 195 & 11 & 162 \\
\hline Pontine & Palmarola & $40^{\circ} 56^{\prime} 13^{\prime \prime}$ & $12^{\circ} 51^{\prime} 29^{\prime \prime}$ & 1.38 & 253 & 9 & 34 \\
\hline Pontine & Ponza & $40^{\circ} 54^{\prime}$ & $12^{\circ} 58^{\prime}$ & 7.54 & 280 & 21 & 33 \\
\hline Pontine & Santo Stefano & $40^{\circ} 47^{\prime} 22^{\prime \prime}$ & $13^{\circ} 27^{\prime} 15^{\prime \prime}$ & 0.32 & 84 & 2 & 47 \\
\hline Pontine & Ventotene & $40^{\circ} 48^{\prime}$ & $13^{\circ} 26^{\prime}$ & 1.35 & 139 & 7 & 46 \\
\hline Pontine & Zannone & $40^{\circ} 58^{\prime}$ & $13^{\circ} 3^{\prime}$ & 1.12 & 194 & 5 & 27.6 \\
\hline Tremiti & Caprara & $42^{\circ} 08^{\prime} 08^{\prime \prime}$ & $15^{\circ} 30^{\prime} 45^{\prime \prime}$ & 0.45 & 53 & 4.7 & 24 \\
\hline Tremiti & Cretaccio & $42^{\circ} 7^{\prime} 21.38^{\prime \prime}$ & $15^{\circ} 30^{\prime} 0.14^{\prime \prime}$ & 0.035 & 30 & 1.3 & 23.25 \\
\hline Tremiti & Pianosa & $42^{\circ} 13^{\prime} 23^{\prime \prime}$ & $15^{\circ} 45^{\prime} 2^{\prime \prime}$ & 0.13 & 15 & 26 & 33.9 \\
\hline Tremiti & Scoglio Elefante & $42^{\circ} 06^{\prime} 37.39^{\prime \prime}$ & $15^{\circ} 29^{\prime} 32.89^{\prime \prime}$ & 0.0004 & 20 & 0.3 & 22.2 \\
\hline Tremiti & San Domino & $42^{\circ} 06^{\prime} 08^{\prime \prime}$ & $15^{\circ} 29^{\prime} 17^{\prime \prime}$ & 2.08 & 116 & 9.7 & 22.05 \\
\hline Tremiti & San Nicola & $42^{\circ} 07^{\prime} 20^{\prime \prime}$ & $15^{\circ} 30^{\prime} 36^{\prime \prime}$ & 0.42 & 75 & 3.7 & 22.9 \\
\hline Tuscany & Mount Argentario & $42^{\circ} 23^{\prime} 54^{\prime \prime}$ & $11^{\circ} 08^{\prime} 34^{\prime \prime}$ & 60.3 & 635 & 37 & 0 \\
\hline Tuscany & Capraia & $43^{\circ} 03^{\prime} 0^{\prime \prime}$ & $9^{\circ} 51^{\prime} 0^{\prime \prime}$ & 19.5 & 447 & 19.3 & 27.07 \\
\hline Tuscany & Cerboli & $42^{\circ} 51^{\prime} 30^{\prime \prime}$ & $10^{\circ} 32^{\prime} 53^{\prime \prime}$ & 0.050625 & 71 & 1.7 & 6.7 \\
\hline Tuscany & Elba & $42^{\circ} 45^{\prime} 46^{\prime \prime}$ & $10^{\circ} 14 ’ 22^{\prime \prime}$ & 223.5 & 1019 & 147 & 9.32 \\
\hline Tuscany & Formica di Burano & $42^{\circ} 22^{\prime} 49^{\prime \prime}$ & $11^{\circ} 18^{\prime} 41^{\prime \prime}$ & 0.0072 & 0 & 0.39 & 4.2 \\
\hline Tuscany & Formica di Grosseto & $42^{\circ} 34^{\prime} 36^{\prime \prime}$ & $10^{\circ} 53^{\prime} 0^{\prime \prime}$ & 0.145 & 11 & 1 & 13.9 \\
\hline Tuscany & Giannutri & $42^{\circ} 15^{\prime} 14^{\prime \prime}$ & $11^{\circ} 06^{\prime} 13^{\prime \prime}$ & 2.4 & 93 & 11 & 21.42 \\
\hline Tuscany & Giglio & $42^{\circ} 21^{\prime} 00^{\prime \prime}$ & $10^{\circ} 54^{\prime} 00^{\prime \prime}$ & 21.2 & 498 & 28 & 26.2 \\
\hline Tuscany & Gorgona & $43^{\circ} 25^{\prime} 45^{\prime \prime}$ & $9^{\circ} 54^{\prime}$ & 2.2 & 255 & 5.5 & 33.46 \\
\hline Tuscany & La Scola & $42^{\circ} 35^{\prime} 01.76^{\prime \prime}$ & $10^{\circ} 06^{\prime} 22.72^{\prime \prime}$ & 0.014 & 34 & 0.5 & 57 \\
\hline Tuscany & Montecristo & $42^{\circ} 20^{\prime}$ & $10^{\circ} 18.30^{\prime}$ & 10.4 & 645 & 16 & 69.58 \\
\hline Tuscany & Pianosa (Tuscany) & $42^{\circ} 35^{\prime}$ & $10^{\circ} 05^{\prime}$ & 10.3 & 30 & 1.3 & 42.35 \\
\hline Tuscany & Sparviero & $42^{\circ} 47^{\prime} 49.3^{\prime \prime}$ & $10^{\circ} 42^{\prime} 44.4 \prime$ & 0.01375 & 38 & 0.8 & 1.38 \\
\hline Tuscany (Elba) & Argentarola & $42^{\circ} 25^{\prime} 6.7^{\prime \prime}$ & $11^{\circ} 4{ }^{\prime} 53^{\prime \prime}$ & 0.012 & 43 & 0.46 & 11.6 \\
\hline Tuscany (Elba) & Gemini Fuori & $42^{\circ} 43^{\prime} 02.53^{\prime \prime}$ & $10^{\circ} 22^{\prime} 22.27^{\prime \prime}$ & 0.01875 & 42 & 0.5 & 25.5 \\
\hline Tuscany (Elba) & Gemini Terra & $42^{\circ} 43^{\prime} 06.78^{\prime \prime}$ & $10^{\circ} 22^{\prime} 27.47^{\prime \prime}$ & 0.01437 & 25 & 0.6 & 25.25 \\
\hline Tuscany (Elba) & Scoglio Remaiolo & $42^{\circ} 42^{\prime} 35.35^{\prime \prime}$ & $10^{\circ} 24^{\prime} 46.75^{\prime \prime}$ & 0.001465 & 0 & 0.16 & 25.03 \\
\hline Tuscany (Elba) & Isolotto dei Topi & $42^{\circ} 52^{\prime} 15^{\prime \prime}$ & $10^{\circ} 25^{\prime} 24^{\prime \prime}$ & 0.01375 & 34 & 0.4 & 9 \\
\hline Tuscany (Elba) & Isolotto Liscoli & $42^{\circ} 44^{\prime} 39.69^{\prime \prime}$ & $10^{\circ} 25^{\prime} 04.75^{\prime \prime}$ & 0.0053 & 10 & 0.17 & 21.35 \\
\hline Tuscany (Elba) & Isolotto Ortano & $42^{\circ} 47^{\prime} 24.80^{\prime \prime}$ & $10^{\circ} 26^{\prime} 01.27^{\prime \prime}$ & 0.012 & 22 & 0.48 & 16 \\
\hline Tuscany (Elba) & Scoglio Paolina & $42^{\circ} 47^{\prime} 21.57^{\prime \prime}$ & $10^{\circ} 13^{\prime} 52.59^{\prime \prime}$ & 0.0025 & 13 & 0.2 & 26.5 \\
\hline Tuscany (Elba) & Scoglietto Portoferraio & $42^{\circ} 49^{\prime} 17.42^{\prime \prime}$ & $10^{\circ} 19^{\prime} 43.45^{\prime \prime}$ & 0.0000249 & 20 & 0.44 & 18.32 \\
\hline Sicily & Pantelleria & $36^{\circ} 47^{\prime} 27^{\prime \prime}$ & $11^{\circ} 59^{\prime} 38^{\prime \prime}$ & 86 & 591 & 51.5 & 70.85 \\
\hline Sicily & Ustica & $38^{\circ} 43^{\prime}$ & $13^{\circ} 11^{\prime}$ & 8.6 & 238 & 16 & 53 \\
\hline
\end{tabular}


Table 2. Protection status of studied islands.

Tabela 2. Estatuto de proteção das ilhas em estudo.

\begin{tabular}{lll}
\hline Archipelago & Island & Protection \\
\hline Aegadian & Favignana & The island is Natura 2000 site ITA010004. The island is part of the \\
& & Natura 2000 site \\
& ZPS ITA010027. The sea surrounding the island belongs to the "Area \\
& Marina Protetta delle Isole Egadi"
\end{tabular}

\begin{tabular}{ll}
\hline Aegadian Levanzo & The island is Natura 2000 site ITA010004. \\
The island is also part of the Natura2000 site ITA010027. The sea \\
surrounding the island belongs to the "Area Marina Protetta delle Isole \\
Egadi"
\end{tabular}

\section{Reference}

http://natura2000.eea.europa.eu/Natura2000/SDF.aspx?site=ITA010004 http://www.ampisoleegadi.it/; http://www.lasiciliainrete.it/NATURA/trapani/ Riserva_isole_egadi/riserva_isole_egadi.htm; http://natura2000.eea.europa.eu/ Natura2000/SDF.aspx?site=ITA010027

http://natura2000.eea.europa.eu/Natura2000/SDF.aspx?site=ITA010003; http://www.ampisoleegadi.it/; http://www.lasiciliainrete.it/NATURA/trapani/ Riserva_isole_egadi/riserva_isole_egadi.htm; http://natura2000.eea.europa.eu/ Natura2000/SDF.aspx?site=ITA010027

Aegadian Marettimo The island is Natura 2000 site ITA010002. The island is also part of the Natura 2000 site ITA010027. The sea surrounding the island belongs to the "Area Marina Protetta delle Isole Egadi"
http://natura2000.eea.europa.eu/Natura2000/SDF.aspx?site=ITA010002 http://www.ampisoleegadi.it/; http://www.lasiciliainrete.it/NATURA/trapani/ Riserva_isole_egadi/riserva_isole_egadi.htm; http://natura2000.eea.europa.eu/ Natura2000/SDF.aspx?site=ITA010027

\begin{tabular}{|c|c|c|c|}
\hline Aeolian & Alicudi & $\begin{array}{l}\text { About } 75 \% \text { of island is part of Natura } 2000 \text { site ITA } 030023 \text { and } \\
\text { ITA } 030044\end{array}$ & http://natura2000.eea.europa.eu/natura2000/SDF.aspx?site=ITA030023 \\
\hline Aeolian & Basiluzzo & All island is part of the Natura 2000 site ZPS ITA030044 & $\begin{array}{l}\text { http://www.artasicilia.eu/old_site/web/natura2000/schede_natura_sicilia/CART_ } \\
\text { CTR10_PDF/577140.pdf }\end{array}$ \\
\hline Aeolian & Bottaro & All island is part of the Natura 2000 site ZPS ITA030044 & $\begin{array}{l}\text { http://www.artasicilia.eu/old_site/web/natura2000/schede_natura_sicilia/CART_ } \\
\text { CTR10_PDF/577140.pdf }\end{array}$ \\
\hline Aeolian & Filicudi & $\begin{array}{l}\text { About } 82 \% \text { of island is part of Natura } 2000 \text { site ITA030023 and } \\
\text { ITA030044 }\end{array}$ & http://natura2000.eea.europa.eu/Natura2000/SDF.aspx?site=ITA030024 \\
\hline Aeolian & Lipari & $\begin{array}{l}\text { About } 67 \% \text { of island is part of Natura } 2000 \text { site ITA030030 and } \\
\text { ITA030044 }\end{array}$ & http://natura2000.eea.europa.eu/Natura2000/SDF.aspx?site=ITA030030 \\
\hline Aeolian & Lisca Bianca & All island is part of the Natura 2000 site ZPS ITA030044 & $\begin{array}{l}\text { http://www.artasicilia.eu/old_site/web/natura2000/schede_natura_sicilia/CART_ } \\
\text { CTR10_PDF/577140.pdf }\end{array}$ \\
\hline Aeolian & Panarea & $\begin{array}{l}\text { About } 78 \% \text { of island is part of Natura } 2000 \text { site ITA030025. All island } \\
\text { is also part of the Natura } 2000 \text { site ITA030044 }\end{array}$ & $\begin{array}{l}\text { http://natura2000.eea.europa.eu/Natura2000/SDF.aspx?site=ITA030025; http:// } \\
\text { www.artasicilia.eu/old_site/web/natura2000/schede_natura_sicilia/CART_ } \\
\text { CTR10_PDF/577140.pdf }\end{array}$ \\
\hline Aeolian & Pietra del Bagno & All island is part of the Natura 2000 site ITA030044 & http://www.portaledelleisoleolie.it/lipari_sud_sic_zps.pdf \\
\hline Aeolian & Salina & $\begin{array}{l}\text { Two SICs have been identified on the island: ITA030028 and } \\
\text { ITA030029. Together, they cover about } 72 \% \text { of island surface. A } \\
\text { marine SIC is ITA030041. }\end{array}$ & $\begin{array}{l}\text { http://natura2000.eea.europa.eu/Natura2000/SDF.aspx?site=ITA030028; http:// } \\
\text { natura2000.eea.europa.eu/Natura2000/SDF.aspx?site=ITA030029 }\end{array}$ \\
\hline
\end{tabular}

\begin{tabular}{lll}
\hline Aeolian & $\begin{array}{l}\text { Scoglio } \\
\text { Faraglione }\end{array}$ & None \\
\hline Aeolian & Stromboli & $\begin{array}{l}\text { About 87\% of island is part of Natura } 2000 \text { site ITA030026 and all } \\
\text { the island is included in ITA030044 }\end{array}$ \\
\hline Aeolian & Strombolicchio & $\begin{array}{l}\text { About 25\% of island is part of Natura 2000 site ITA030026, and all } \\
\text { the island is included in both ITA030026 and ITA030044. The island } \\
\text { has been deigned as a Strict Nature Reserve }\end{array}$ \\
\hline Aeolian & Vulcano & $\begin{array}{l}\text { About 77\% of island is part of Natura 2000 site ITA030027 and } \\
\text { ITA030044 }\end{array}$ \\
\hline Campane & Capri & $\begin{array}{l}\text { Two Natura 2000 sites have been identified on the island: IT8030038 } \\
\text { and IT8030039. Together, they cover about 47\% of island surface. }\end{array}$ \\
\hline Campane & Ischia & $\begin{array}{l}\text { The island includes four Natura 2000 sites: IT8030005, IT8030022 } \\
\text { IT8030026, IT8030034. Altogether, they cover about 45\% of the } \\
\text { island's surface }\end{array}$
\end{tabular}

\begin{tabular}{lll}
\hline Campane & Vivara & $\begin{array}{l}\text { The island is Natura } 2000 \text { site IT8030012. It is also classified as } \\
\text { "Riserva Naturale Statale" }\end{array}$ \\
\hline Pelagian & Lampedusa & $\begin{array}{l}\text { About } 70 \% \text { of island area is Natura } 2000 \text { site ITA040002. The island } \\
\text { is also part of the Natura } 2000 \text { site ITA040013. A small fraction of } \\
\text { the island's surface is protected as "Riserva naturale orientata Isola di } \\
\text { Lampedusa" }\end{array}$
\end{tabular}

\begin{tabular}{|c|c|c|}
\hline Pelagian & Lampione & $\begin{array}{l}\text { All island is part of Natura } 2000 \text { site ITA0 } 40002 \text {. The island is also } \\
\text { part of the Natura } 2000 \text { site ITA040013. All island is part of "Riserva } \\
\text { naturale orientata/integrale Isola di Linosa e Lampione" }\end{array}$ \\
\hline
\end{tabular}

Pelagian Linosa About $80 \%$ is part of Natura 2000 site ITA040001. All island is
included in Natura 2000 site ITA0 40013 . About $50 \%$ of the island is protected as "Riserva naturale orientata/integrale Isola di Linosa e Lampione"

\begin{tabular}{lll}
\hline Pontine & Palmarola & $\begin{array}{l}\text { All island is included in Natura } 2000 \text { site IT6040020 All island is a } \\
\text { strict nature reserve within the "Riserva naturale orientata/integrale } \\
\text { Isola di Linosa e Lampione" }\end{array}$ \\
\hline Pontine & Ponza & All island is included in Natura 2000 site IT6040019 \\
\hline Pontine & Santo Stefano & $\begin{array}{l}\text { All island is included in Natura } 2000 \text { site IT6040020. The island } \\
\text { is also part of the Riserva Naturale Statale denominata "Isole di } \\
\text { Ventotene e S. Stefano" }\end{array}$
\end{tabular}

http://natura2000.eea.europa.eu/Natura2000/SDF.aspx?site=ITA030026

http://natura2000.eea.europa.eu/Natura2000/SDF.aspx?site=ITA030026 http://natura2000.eea.europa.eu/Natura2000/SDF.aspx?site=ITA030027

http://natura2000.eea.europa.eu/Natura2000/SDF.aspx?site=IT8030038; http:// natura2000.eea.europa.eu/Natura2000/SDF.aspx?site=IT8030039

http://natura2000.eea.europa.eu/Natura2000/SDF.aspx?site=IT8030005; http:// natura2000.eea.europa.eu/Natura2000/SDF.aspx?site=IT8030026 http://natura2000.eea.europa.eu/Natura2000/SDF.aspx?site=IT8030034 http://natura2000.eea.europa.eu/Natura2000/SDF.aspx?site=IT8030022 http://natura2000.eea.europa.eu/Natura2000/SDF.aspx?site=IT8030012

http://natura2000.eea.europa.eu/Natura2000/SDF.aspx?site=ITA040002; http:// natura2000.eea.europa.eu/Natura2000/SDF.aspx?site=ITA040013

http://natura2000.eea.europa.eu/Natura2000/SDF.aspx?site=ITA040002; http:// natura2000.eea.europa.eu/Natura2000/SDF.aspx?site=ITA0 40013

http://natura2000.eea.europa.eu/Natura2000/SDF.aspx?site=ITA040001

http://natura2000.eea.europa.eu/Natura2000/SDF.aspx?site=IT6040020

http://natura2000.eea.europa.eu/Natura2000/SDF.aspx?site=IT6040019 http://natura2000.eea.europa.eu/Natura2000/SDF.aspx?site=IT6040020; http:// www.comune.ventotene.lt.it/parchi_riserve.htm 
Table 2. Continuação

\section{Tabela 2. Continuation}

\begin{tabular}{|c|c|c|c|}
\hline Pontine & Ventotene & $\begin{array}{l}\text { All island is included in Natura } 2000 \text { site IT6040020. The island is also } \\
\text { part of the Riserva Naturale Statale denominata "Isole di Ventotene e } \\
\text { S. Stefano" }\end{array}$ & $\begin{array}{l}\text { http://natura2000.eea.europa.eu/Natura2000/SDF.aspx?site=IT6040020; http:// } \\
\text { www.comune.ventotene.lt.it/parchi_riserve.htm }\end{array}$ \\
\hline Pontine & Zannone & $\begin{array}{l}\text { All island is included in Natura } 2000 \text { site IT6040020. The island is } \\
\text { part of "Parco Nazionale del Circeo". }\end{array}$ & $\begin{array}{l}\text { http://natura2000.eea.europa.eu/Natura2000/SDF.aspx?site=IT6040020; http:// } \\
\text { www.parcocirceo.it/ita_245_isola-di-zannone.html }\end{array}$ \\
\hline Tremiti & Caprara & $\begin{array}{l}\text { The island is part of Natura } 2000 \text { sites IT911011 and IT9110040. The } \\
\text { island is part of "Parco Nazionale del Gargano" }\end{array}$ & $\begin{array}{l}\text { http://natura2000.eea.europa.eu/Natura2000/SDF.aspx?site=IT9110011; http:// } \\
\text { natura2000.eea.europa.eu/Natura2000/SDF.aspx?site=IT9110040 }\end{array}$ \\
\hline Tremiti & Cretaccio & $\begin{array}{l}\text { The island is part of Natura } 2000 \text { sites IT911011 and IT9110040. The } \\
\text { island is part of "Parco Nazionale del Gargano" }\end{array}$ & $\begin{array}{l}\text { http://natura2000.eea.europa.eu/Natura2000/SDF.aspx?site=IT9110011; http:// } \\
\text { natura2000.eea.europa.eu/Natura2000/SDF.aspx?site=IT9110040 }\end{array}$ \\
\hline Tremiti & Pianosa & $\begin{array}{l}\text { The island is part of Natura } 2000 \text { sites IT911011 and IT9110040. The } \\
\text { island is part of "Parco Nazionale del Gargano" }\end{array}$ & $\begin{array}{l}\text { http://natura2000.eea.europa.eu/Natura2000/SDF.aspx?site=IT9110011; http:// } \\
\text { natura2000.eea.europa.eu/Natura2000/SDF.aspx?site=IT9110040 }\end{array}$ \\
\hline Tremiti & Scoglio Elefante & $\begin{array}{l}\text { The islet is part of Natura } 2000 \text { sites IT911011 and IT9110040. The } \\
\text { island is part of "Parco Nazionale del Gargano" }\end{array}$ & $\begin{array}{l}\text { http://natura2000.eea.europa.eu/Natura2000/SDF.aspx?site=IT9110011; http:// } \\
\text { natura2000.eea.europa.eu/Natura2000/SDF.aspx?site=IT9110040 }\end{array}$ \\
\hline Tremiti & San Domino & $\begin{array}{l}\text { The island is part of Natura } 2000 \text { sites IT911011 and IT9110040. The } \\
\text { island is part of "Parco Nazionale del Gargano" }\end{array}$ & $\begin{array}{l}\text { http://natura2000.eea.europa.eu/Natura2000/SDF.aspx?site=IT9110011; http:// } \\
\text { natura2000.eea.europa.eu/Natura2000/SDF.aspx?site=IT9110040 }\end{array}$ \\
\hline Tremiti & San Nicola & $\begin{array}{l}\text { The island is part of Natura200 sites IT911011 and IT9110040. The } \\
\text { island is part of Parco Nazionale del Gargano }\end{array}$ & $\begin{array}{l}\text { http://natura2000.eea.europa.eu/Natura2000/SDF.aspx?site=IT9110011; http:// } \\
\text { natura2000.eea.europa.eu/Natura2000/SDF.aspx?site=IT9110040 }\end{array}$ \\
\hline Tuscany & $\begin{array}{l}\text { Mount } \\
\text { Argentario }\end{array}$ & $\begin{array}{l}\text { The island is almost completely included in the Natura } 2000 \text { site } \\
\text { IT51A0025. }\end{array}$ & http://natura2000.eea.europa.eu/Natura2000/SDF.aspx?site=IT51A0025 \\
\hline Tuscany & Capraia & $\begin{array}{l}\text { The island is Natura } 2000 \text { site IT5160006. All island except the } \\
\text { inhabited centre is Natura } 2000 \text { site IT5160007 and is part of the } \\
\text { "Parco Nazionale dell'Arcipelago Toscano" }\end{array}$ & $\begin{array}{l}\text { http://natura2000.eea.europa.eu/Natura2000/SDF.aspx?site=IT5160006; http:// } \\
\text { natura2000.eea.europa.eu/Natura2000/SDF.aspx?site=IT5160007 }\end{array}$ \\
\hline Tuscany & Cerboli & The island is part of Natura 2000 site IT5160011. & http://natura2000.eea.europa.eu/Natura2000/SDF.aspx?site=IT5160011 \\
\hline Tuscany & Elba & $\begin{array}{l}\text { The island includes two Natura } 2000 \text { sites: IT5 } 160102 \text { and } \\
\text { IT5160012. Together they cover about } 51 \% \text { of the island's area. The } \\
\text { island is also included for about } 50 \% \text { of its surface in the "Parco } \\
\text { Nazionale dell'Arcipelago Toscano" }\end{array}$ & $\begin{array}{l}\text { http://natura2000.eea.europa.eu/Natura2000/SDF.aspx?site=IT5160102; http:// } \\
\text { natura2000.eea.europa.eu/Natura2000/SDF.aspx?site=IT5160102 }\end{array}$ \\
\hline Tuscany & $\begin{array}{l}\text { Formica di } \\
\text { Burano }\end{array}$ & The island is Natura 2000 site IT51A0035 & http://natura2000.eea.europa.eu/Natura2000/SDF.aspx?site=IT51A0035 \\
\hline Tuscany & $\begin{array}{l}\text { Formica di } \\
\text { Grosseto }\end{array}$ & The island is Natura 2000 site IT51A0022. & http://natura2000.eea.europa.eu/Natura2000/SDF.aspx?site=IT51A0022 \\
\hline Tuscany & Giannutri & $\begin{array}{l}\text { The island is completely included in the Natura } 2000 \text { site IT51A0024. } \\
\text { It is included in the "Parco Nazionale dell'Arcipelago Toscano" }\end{array}$ & http://natura2000.eea.europa.eu/Natura2000/SDF.aspx?site=IT51A0024 \\
\hline Tuscany & Giglio & $\begin{array}{l}\text { The island is almost completely included in the Natura } 2000 \text { site } \\
\text { IT51A0023. Less than } 50 \% \text { of island's surface is included in the } \\
\text { "Parco Nazionale dell'Arcipelago Toscano" }\end{array}$ & http://natura2000.eea.europa.eu/Natura2000/SDF.aspx?site=IT51A0023 \\
\hline Tuscany & Gorgona & $\begin{array}{l}\text { Virtually all island is Natura } 2000 \text { site IT5160002 and is part of the } \\
\text { "Parco Nazionale dell'Arcipelago Toscano" }\end{array}$ & http://natura2000.eea.europa.eu/Natura2000/SDF.aspx?site=IT5160002 \\
\hline Tuscany & La Scola & $\begin{array}{l}\text { The island is Natura } 2000 \text { site IT5160013. It is also completely } \\
\text { included in the "Parco Nazionale dell'Arcipelago Toscano" }\end{array}$ & http://natura2000.eea.europa.eu/Natura2000/SDF.aspx?site=IT5160013 \\
\hline Tuscany & Montecristo & $\begin{array}{l}\text { The island is Natura } 2000 \text { site IT5160014. It is also completely } \\
\text { included in the Parco Nazionale dell'Arcipelago Toscano. }\end{array}$ & http://natura2000.eea.europa.eu/Natura2000/SDF.aspx?site=IT5160014 \\
\hline Tuscany & $\begin{array}{l}\text { Pianosa } \\
\text { (Tuscany) }\end{array}$ & $\begin{array}{l}\text { The island is Natura } 2000 \text { site IT5160013. It is also completely } \\
\text { included in the "Parco Nazionale dell'Arcipelago Toscano" }\end{array}$ & http://natura2000.eea.europa.eu/Natura2000/SDF.aspx?site=IT5160013 \\
\hline Tuscany & Sparviero & The island is Natura 2000 site IT51A0035 & http://natura2000.eea.europa.eu/Natura2000/SDF.aspx?site=IT51A0035 \\
\hline Tuscany(Elba) & Argentarola & $\begin{array}{l}\text { The island is almost completely included in the Natura } 2000 \text { site } \\
\text { IT51A0038. }\end{array}$ & http://natura2000.eea.europa.eu/Natura2000/SDF.aspx?site=IT51A0038 \\
\hline Tuscany(Elba) & Gemini Fuori & $\begin{array}{l}\text { The islet is part of Natura } 2000 \text { site IT5160011. It is part of the } \\
\text { "Parco Nazionale dell'Arcipelago Toscano" }\end{array}$ & http://natura2000.eea.europa.eu/Natura2000/SDF.aspx?site=IT5160011 \\
\hline Tuscany(Elba) & Gemini Terra & $\begin{array}{l}\text { The islet is part of Natura } 2000 \text { site IT5160011. It is part of the } \\
\text { "Parco Nazionale dell'Arcipelago Toscano" }\end{array}$ & http://natura2000.eea.europa.eu/Natura2000/SDF.aspx?site=IT5160011 \\
\hline Tuscany(Elba) & $\begin{array}{l}\text { Scoglio } \\
\text { Remaiolo }\end{array}$ & The islet is part of Natura 2000 site IT5160102. & http://natura2000.eea.europa.eu/Natura2000/SDF.aspx?site=IT5160102 \\
\hline Tuscany(Elba) & Isolotto dei Topi & $\begin{array}{l}\text { The islet is part of Natura } 2000 \text { site IT5160011. It is part of the } \\
\text { "Parco Nazionale dell'Arcipelago Toscano" }\end{array}$ & http://natura2000.eea.europa.eu/Natura2000/SDF.aspx?site=IT5160011 \\
\hline Tuscany(Elba) & Isolotto Liscoli & The islet is part of Natura 2000 site IT5160102. & http://natura2000.eea.europa.eu/Natura2000/SDF.aspx?site=IT5160102 \\
\hline Tuscany(Elba) & Isolotto Ortano & $\begin{array}{l}\text { The islet is part of Natura } 2000 \text { site IT5160102. It is part of the } \\
\text { "Parco Nazionale dell'Arcipelago Toscano" }\end{array}$ & http://natura2000.eea.europa.eu/Natura2000/SDF.aspx?site=IT5160102 \\
\hline Tuscany(Elba) & Scoglio Paolina & None & \\
\hline Tuscany(Elba) & $\begin{array}{l}\text { Scoglietto } \\
\text { Portoferraio }\end{array}$ & $\begin{array}{l}\text { The island is part of Natura } 2000 \text { site IT5160011. It is part of the } \\
\text { "Parco Nazionale dell'Arcipelago Toscano" }\end{array}$ & http://natura2000.eea.europa.eu/Natura2000/SDF.aspx?site=IT5160011 \\
\hline Sicily & Pantelleria & $\begin{array}{l}\text { About } 76 \% \text { of island is included into two Natura } 2000 \text { sites: } \\
\text { ITA010019 and ITA010020. About } 30 \% \text { of island's area is protected } \\
\text { as "Riserva naturale orientata Isola di Ustica" }\end{array}$ & $\begin{array}{l}\text { http://natura2000.eea.europa.eu/Natura2000/SDF.aspx?site=ITA010019; } \\
\text { http://natura2000.eea.europa.eu/Natura2000/SDF.aspx?site=ITA010020 }\end{array}$ \\
\hline Sicily & Ustica & $\begin{array}{l}\text { About } 40 \% \text { of island is part of Natura } 2000 \text { site ITA020010. About } \\
24 \% \text { of island's area is protected as "Riserva naturale orientata Isola } \\
\text { di Ustica" }\end{array}$ & http://natura2000.eea.europa.eu/Natura2000/SDF.aspx?site=ITA020010 \\
\hline
\end{tabular}


three aspects were evaluated using information provided in Aliquò et al. (2006). Geographical distribution was evaluated with reference to the number of Italian administrative mainland regions from which each species is known. Species occurring in less than four regions ( $<20 \%$ of regions) were considered as geographically rare. Species associated with coastal habitats were considered as having restricted habitat specificity. Species reported as scarce by Aliquò et al. (2006) were considered as having scarce populations. Then, an eight-score scale was created that reflected different types of rarity and commonness, and each species was assigned to a score as follow: 1: species that are not rare; 2 : scarce species (i.e. species rare for abundance); 3: species with narrow habitat specificity; 4: restricted species (i.e. species rare by range); 5: scarce species with narrow habitat specificity (i.e. species rare for both habitat specificity and abundance); 6: scarce and restricted species (i.e. species rare for both geographical range and abundance); 7: restricted species with narrow habitat specificity (i.e. species rare for both habitat specificity and geographical distribution); 8: restricted and scarce species with narrow habitat specificity (i.e. species rare for geographical distribution, habitat specificity and abundance). This weighting scheme assigns higher importance to geographical rarity which is appropriate for the purpose of our study because species with a narrow geographical distribution are more vulnerable at a global or regional level (e.g. endemics) (Kattan, 1992). Using this weighting scheme in the BCC calculation, species common for all rarity measures received an $\alpha$-value of 1 , whereas species rare for all three aspects received an $\alpha$-value of 8 . The BCC calculated using this scheme will be referred to as BCC2.

In a third approach, we strictly focused on the type of distribution shown by species. For this, we divided the species into the following categories: species endemic to single islands (SIE); species endemic to an archipelago (END); species occurring on one or more of the study islands, but not on the Italian mainland or major islands (Sardinia and Sicily), which is the case of species occurring on the African on Greek coasts (NIT); species occurring on the Italian mainland or major islands with highly fragmented distribution (FRG); species that are widespread on the Italian mainland (WID). For the calculation of the BCC index, the following arrangement of weights was used: $\operatorname{SIE}(\alpha=16), \operatorname{END}(\alpha=8)$, NIT $(\alpha=4)$, FRG $(\alpha=2)$, WID $(\alpha=1)$. In this case, weights followed a geometric series to take into account various sources of incertitude (see Fattorini, 2006a). In general, it is unlikely that species found only on islands will be later found also on mainland areas and endemics are obviously an important conservation target in island conservation; moreover, single island endemics are much more valued than species which occur on more than one island. A the other extreme, the assignment of a species to the FRG category may be problematic, because it is difficult to establish if a fragmented distribution reflects a true state of affairs or is due to the lack of knowledge, thus species with an assumed fragmented distribution have a score only slightly superior to that of widespread species. Finally, the intermediate weight assigned to the NIT category is due to the fact that species occurring on Italian islands, but not on other Italian areas, are of high conservation value from a national perspective, even if they may be largely distributed in other countries. This criterion is similar to the IUCN procedure for regional red list assessments (http://www.iucnredlist.org/documents/ reg_guidelines_en.pdf). The BCC calculated using this scheme will be referred to as BCC3.

Finally, as a forth criterion, we calculated species rarity using the perimeter of the inhabited islands. In the BCC1 index, we calculated species rarity on the basis of the number of occupied islands. However, the islands included in our analysis have enormous differences in size, so a species living exclusively in a very small island should be considered much rarer than another living in a large island. To explore this form of rarity, we expressed species rarity as the inverse of the summed perimeter of the islands where the species lives. The rationale for using island's perimeter is due to the prevailing habitat type, i.e. coastal areas, whose extension should be more related with perimeter than area. Because this index is intimately related with the $\mathrm{BCC} 1$, but uses island perimeter instead of island number, we called it BCC1p.

The same rarity measures were used to calculate the respective $\mathrm{BCW}$ indices, which will be refereed to as $\mathrm{BCW} 1$, $\mathrm{BCW} 2, \mathrm{BCW} 3$, and $\mathrm{BCW} 1 \mathrm{p}$, respectively.

To investigate if the four BCC indices are influenced by island geography, we correlated their values with island area, elevation and distance to the closest mainland using a Pearson correlation coefficient. For each BCC index, we considered the islands included in the third quartile of the distribution of BCC values as priority islands. Then, we compared the various indices to assess the percentage of "priority islands" shared by two or more indices. Finally, we used ANOVAs to test if islands selected as priority islands by the four indices showed significant differences in their geographical characteristics, with LSD post hoc tests for pairwise comparisons. The same approach was used for the four BCW indices. Probability levels were set at 0.05 in all tests.

\section{RESULTS}

Values of $\mathrm{BCC} 1, \mathrm{BCC} 2, \mathrm{BCC} 3$, and $\mathrm{BCC} 1 \mathrm{p}$ are given in Table 3. Values of BCC1 ranged from 0.004 to 0.827 (mean $\pm \mathrm{SE}=0.149 \pm 0.019)$. Values of BCC2 ranged from 0.000 to 0.952 (mean $\pm \mathrm{SE}=0.369 \pm 0.034$ ), but only one island (Vivara) had a value of zero. Values of BCC3 ranged from 0.000 to 0.644 (mean $\pm \mathrm{SE}=0.149 \pm 0.023$ ), with nine islands having a value of zero. Values of $\mathrm{BCCl}$ p ranged from 0.0004 to 0.381 (mean $\pm S E=0.020 \pm 0.007)$.

Values of $\mathrm{BCW} 1, \mathrm{BCW} 2, \mathrm{BCW} 3$, and $\mathrm{BCW} 1 \mathrm{p}$ are also given in Table 3. Values of BCW1 ranged from 0.000 to 0.161 (mean $\pm \mathrm{SE}=0.029 \pm 0.005$ ). Values of $\mathrm{BCW} 2$ ranged from 0.000 to 0.225 (mean $\pm \mathrm{SE}=0.047 \pm 0.006$ ), but only one island (Vivara) had values of zero. Values of $\mathrm{BCW} 3$ ranged from 0.000 to 0.210 (mean $\pm \mathrm{SE}=0.028 \pm$ 0.005 ), with nine islands having a value of zero. Values of $\mathrm{BCC} 1 \mathrm{p}$ ranged from 0.0002 to 0.3688 (mean $\pm \mathrm{SE}=0.0264$ $\pm 0.007)$.

On average, $\mathrm{BCC} 2$ attained higher values than $\mathrm{BCC} 1$ (paired t-test, $\mathrm{t}=6.188, \mathrm{p}<0.0001)$ and BCC3 $(\mathrm{t}=14.333$, $\mathrm{p}<0.0001)$, whereas BCC1 and BCC3 did not show a significant difference in their average values $(t=0.025, \mathrm{p}=$ $0.980)$. BCC1p showed lower values than BCC1 $(t=2.299$, $\mathrm{p}<0.0001), \mathrm{BCC} 2(\mathrm{t}=-10.799, \mathrm{p}<0.0001)$, and BCC3 $(\mathrm{t}$ $=-5.967, \mathrm{p}<0.0001)$. 
Table 3. Values of Biodiversity Conservation Concern (BCC) and Biodiversity Conservation Weight $(\mathrm{BCW})$ calculated for tenebrionid beetles using species rarity (BCC1, BCW1), vulnerability (BCC2, $\mathrm{BCW} 2$ ), biogeographical characterization (BCC3, $\mathrm{BCW}$ ), and perimeter of inhabited islands (BCC1p, BCW1p).

Tabela 3. Valor de Interesse para Conservação da Biodiversidade (BBC) e de Peso para a Conservação da Biodiversidade $(B C W)$ calculado para escaravelhos tenebrionídeos usando a raridade de espécies (BCC1, $B C W 1)$, vulnerabilidade (BCC2, BCW2) caracterização biogeográfica (BCC3, BCW3) e perímetro das ilhas habitadas (BCC1p, BCW1p).

\begin{tabular}{|c|c|c|c|c|c|c|c|c|c|}
\hline Archipelago & Island & BCC1 & BCC2 & BCC3 & BCC1p & BCW1 & BCW2 & BCW3 & BCW1p \\
\hline Aegadian & Favignana & 0.161 & 0.250 & 0.019 & 0.006 & 0.061 & 0.099 & 0.017 & 0.025 \\
\hline Aegadian & Levanzo & 0.067 & 0.262 & 0.000 & 0.003 & 0.017 & 0.066 & 0.000 & 0.008 \\
\hline Aegadian & Marettimo & 0.274 & 0.509 & 0.154 & 0.013 & 0.060 & 0.115 & 0.078 & 0.034 \\
\hline Aeolian & Alicudi & 0.075 & 0.135 & 0.000 & 0.004 & 0.018 & 0.034 & 0.000 & 0.011 \\
\hline Aeolian & Basiluzzo & 0.039 & 0.095 & 0.000 & 0.003 & 0.002 & 0.004 & 0.000 & 0.001 \\
\hline Aeolian & Bottaro & 0.028 & 0.224 & 0.000 & 0.002 & 0.003 & 0.022 & 0.000 & 0.002 \\
\hline Aeolian & Filicudi & 0.117 & 0.210 & 0.009 & 0.007 & 0.024 & 0.044 & 0.004 & 0.017 \\
\hline Aeolian & Lipari & 0.130 & 0.272 & 0.008 & 0.005 & 0.057 & 0.123 & 0.008 & 0.025 \\
\hline Aeolian & Lisca Bianca & 0.017 & 0.071 & 0.000 & 0.001 & 0.001 & 0.004 & 0.000 & 0.001 \\
\hline Aeolian & Panarea & 0.112 & 0.266 & 0.006 & 0.008 & 0.034 & 0.082 & 0.004 & 0.027 \\
\hline Aeolian & Pietra del Bagno & 0.004 & 0.095 & 0.000 & 0.000 & 0.000 & 0.004 & 0.000 & 0.000 \\
\hline Aeolian & Salina & 0.095 & 0.232 & 0.006 & 0.004 & 0.031 & 0.078 & 0.004 & 0.015 \\
\hline Aeolian & Scoglio Faraglione & 0.024 & 0.321 & 0.000 & 0.002 & 0.001 & 0.018 & 0.000 & 0.001 \\
\hline Aeolian & Stromboli & 0.134 & 0.263 & 0.008 & 0.007 & 0.046 & 0.093 & 0.006 & 0.027 \\
\hline Aeolian & Strombolicchio & 0.133 & 0.429 & 0.022 & 0.015 & 0.005 & 0.018 & 0.002 & 0.007 \\
\hline Aeolian & Vulcano & 0.116 & 0.266 & 0.048 & 0.005 & 0.035 & 0.082 & 0.034 & 0.016 \\
\hline Campane & Capri & 0.123 & 0.099 & 0.000 & 0.006 & 0.039 & 0.032 & 0.000 & 0.021 \\
\hline Campane & Ischia & 0.162 & 0.200 & 0.031 & 0.006 & 0.033 & 0.042 & 0.015 & 0.015 \\
\hline Campane & Vivara & 0.021 & 0.000 & 0.000 & 0.001 & 0.001 & 0.000 & 0.000 & 0.001 \\
\hline Pelagian & Lampedusa & 0.420 & 0.571 & 0.238 & 0.016 & 0.161 & 0.225 & 0.210 & 0.074 \\
\hline Pelagian & Lampione & 0.827 & 0.952 & 0.644 & 0.381 & 0.068 & 0.080 & 0.122 & 0.369 \\
\hline Pelagian & Linosa & 0.365 & 0.519 & 0.084 & 0.026 & 0.095 & 0.139 & 0.050 & 0.081 \\
\hline Pontine & Palmarola & 0.098 & 0.232 & 0.117 & 0.012 & 0.011 & 0.026 & 0.029 & 0.015 \\
\hline Pontine & Ponza & 0.101 & 0.151 & 0.027 & 0.005 & 0.023 & 0.036 & 0.015 & 0.013 \\
\hline Pontine & Santo Stefano & 0.127 & 0.127 & 0.104 & 0.018 & 0.016 & 0.016 & 0.029 & 0.026 \\
\hline Pontine & Ventotene & 0.076 & 0.173 & 0.067 & 0.010 & 0.015 & 0.034 & 0.029 & 0.023 \\
\hline Pontine & Zannone & 0.133 & 0.214 & 0.117 & 0.014 & 0.015 & 0.024 & 0.029 & 0.018 \\
\hline Tremiti & Caprara & 0.085 & 0.243 & 0.027 & 0.017 & 0.012 & 0.034 & 0.008 & 0.027 \\
\hline Tremiti & Cretaccio & 0.067 & 0.357 & 0.017 & 0.015 & 0.004 & 0.020 & 0.002 & 0.010 \\
\hline Tremiti & Pianosa & 0.148 & 0.200 & 0.070 & 0.006 & 0.040 & 0.056 & 0.044 & 0.018 \\
\hline Tremiti & Scoglio Elefante & 0.095 & 0.167 & 0.033 & 0.020 & 0.008 & 0.014 & 0.006 & 0.020 \\
\hline Tremiti & San Domino & 0.105 & 0.253 & 0.021 & 0.019 & 0.019 & 0.046 & 0.008 & 0.039 \\
\hline Tremiti & San Nicola & 0.089 & 0.187 & 0.021 & 0.018 & 0.016 & 0.034 & 0.008 & 0.038 \\
\hline Tuscany & Mount Argentario & 0.264 & 0.088 & 0.036 & 0.007 & 0.047 & 0.016 & 0.015 & 0.014 \\
\hline Tuscany & Capraia & 0.224 & 0.190 & 0.115 & 0.010 & 0.055 & 0.048 & 0.065 & 0.029 \\
\hline Tuscany & Cerboli & 0.183 & 0.524 & 0.311 & 0.134 & 0.008 & 0.022 & 0.029 & 0.065 \\
\hline Tuscany & Elba & 0.219 & 0.168 & 0.029 & 0.002 & 0.102 & 0.080 & 0.031 & 0.013 \\
\hline Tuscany & Formica di Burano & 0.029 & 0.857 & 0.467 & 0.003 & 0.000 & 0.012 & 0.015 & 0.001 \\
\hline Tuscany & Formica di Grosseto & 0.083 & 0.786 & 0.467 & 0.003 & 0.002 & 0.022 & 0.029 & 0.001 \\
\hline Tuscany & Giannutri & 0.207 & 0.222 & 0.104 & 0.016 & 0.025 & 0.028 & 0.029 & 0.023 \\
\hline Tuscany & Giglio & 0.233 & 0.272 & 0.098 & 0.006 & 0.067 & 0.080 & 0.065 & 0.021 \\
\hline Tuscany & Gorgona & 0.268 & 0.222 & 0.222 & 0.041 & 0.033 & 0.028 & 0.063 & 0.060 \\
\hline Tuscany & La Scola & 0.298 & 0.500 & 0.244 & 0.023 & 0.024 & 0.042 & 0.046 & 0.022 \\
\hline Tuscany & Montecristo & 0.566 & 0.540 & 0.385 & 0.035 & 0.070 & 0.068 & 0.109 & 0.051 \\
\hline Tuscany & Pianosa (Tuscany) & 0.091 & 0.175 & 0.007 & 0.020 & 0.011 & 0.022 & 0.002 & 0.029 \\
\hline Tuscany & Sparviero & 0.183 & 0.524 & 0.311 & 0.134 & 0.008 & 0.022 & 0.029 & 0.065 \\
\hline Tuscany (Elba) & Argentarola & 0.029 & 0.857 & 0.467 & 0.003 & 0.000 & 0.012 & 0.015 & 0.001 \\
\hline Tuscany (Elba) & Gemini Fuori & 0.029 & 0.857 & 0.467 & 0.003 & 0.000 & 0.012 & 0.015 & 0.001 \\
\hline
\end{tabular}


Table 3. Continuação

Tabela 3. Continuation

\begin{tabular}{llllllllll} 
Tuscany (Elba) & Gemini Terra & 0.093 & 0.524 & 0.311 & 0.003 & 0.004 & 0.022 & 0.029 & 0.001 \\
\hline Tuscany (Elba) & Scoglio Remaiolo & 0.029 & 0.857 & 0.467 & 0.003 & 0.000 & 0.012 & 0.015 & 0.001 \\
\hline Tuscany (Elba) & Isolotto dei Topi & 0.029 & 0.857 & 0.467 & 0.003 & 0.000 & 0.012 & 0.015 & 0.001 \\
\hline Tuscany (Elba) & Isolotto Liscoli & 0.083 & 0.429 & 0.233 & 0.003 & 0.002 & 0.012 & 0.015 & 0.001 \\
\hline Tuscany (Elba) & Isolotto Ortano & 0.029 & 0.857 & 0.467 & 0.003 & 0.000 & 0.012 & 0.015 & 0.001 \\
\hline Tuscany (Elba) & Scoglio Paolina & 0.029 & 0.857 & 0.467 & 0.003 & 0.000 & 0.012 & 0.015 & 0.001 \\
\hline Tuscany (Elba) & Scoglietto Portoferraio & 0.100 & 0.429 & 0.233 & 0.003 & 0.003 & 0.012 & 0.015 & 0.001 \\
\hline Sicily & Pantelleria & 0.431 & 0.534 & 0.159 & 0.009 & 0.135 & 0.173 & 0.115 & 0.033 \\
\hline Sicily & Ustica & 0.220 & 0.341 & 0.049 & 0.011 & 0.078 & 0.125 & 0.040 & 0.047 \\
\hline
\end{tabular}

On average, $\mathrm{BCW} 2$ attained higher values than $\mathrm{BCW} 1$ $(\mathrm{t}=6.891, \mathrm{p}<0.0001)$ and BCW3 $(\mathrm{t}=4.183, \mathrm{p}<0.0001)$, whereas $\mathrm{BCW} 1$ and $\mathrm{BCW} 3$ did not show a significant difference in their average values $(t=0.275, \mathrm{p}=0.784)$. $\mathrm{BCW} 1 \mathrm{p}$ showed lower values than BCC2 $(\mathrm{t}=-2.736$, $\mathrm{p}=0.008$ ), but no significant difference was found for comparisons with BCW 1 and $\mathrm{BCW} 3(\mathrm{t}=-0.369, \mathrm{p}=0.713$, and $\mathrm{t}=-0.258, \mathrm{p}=0.797$, respectively).

The four indices, $\mathrm{BCC} 1, \mathrm{BCC} 2, \mathrm{BCC} 3$, and $\mathrm{BCC} 1 \mathrm{p}$ (Table 3), produced different island rankings which reflect the effect of the geographical characteristics of the islands on their faunal composition. The BCC1 index, which was calculated on the basis of species distribution across islands, was positively correlated with island distance to the mainland $(\mathrm{r}=0.639, \mathrm{p}<0.001)$. This indicates that more remote islands have tenebrionid faunas composed by species occurring on few islands. By contrast, both the BCC2 index, which considered species rarity in terms of mainland distribution, habitat specialization and population abundance, and the BCC3 index, which considered species biogeography, were negatively correlated $(\mathrm{r}=-0.341, \mathrm{p}=0.009$ and $\mathrm{r}=-0.375$, $\mathrm{p}=0.004$, respectively) with island maximum elevation, which indicates that islands with higher maximum elevation (which can be considered a surrogate for habitat diversity) host tenebrionid faunas with a lower concentration of vulnerable and endemic species than environmentally less varied islands. Finally, BCC1p was positively correlated with island distance to the mainland $(\mathrm{r}=0.366, \mathrm{p}=0.005)$.

The BCW1 index was significantly correlated with island perimeter $(r=0.621)$, area $(r=0.536)$, elevation $(r=0.494)$ and distance $(\mathrm{r}=0.554)(\mathrm{p}<0.0001$ in all cases). The BCW2 index was also significantly correlated with island perimeter $(\mathrm{r}=0.453, \mathrm{p}<0.0001)$, area $(\mathrm{r}=0.342, \mathrm{p}=0.009)$, elevation $(\mathrm{r}=0.442, \mathrm{p}=0.001)$ and distance $(\mathrm{r}=0.588, \mathrm{p}<0.0001)$. $\mathrm{BCW} 3$ and $\mathrm{BCW} 1 \mathrm{p}$ were only correlated with distance $(\mathrm{r}=0.588$ and $\mathrm{r}=0.580$, respectively; $\mathrm{p}<0.0001$ in both cases).

To assess index congruence in identifying priority islands, we compared the islands included in the highest third quartile for each index. Within this quartile, 6 islands (Lampione, Montecristo, Lampedusa, Pantelleria, plus Cerboli and Sparviero at the boundary value of the quartile; $40 \%)$ were shared between $\mathrm{BCC} 1$ and $\mathrm{BCC} 2 ; 6$ islands
(Lampione, Montecristo, La Scola, Cerboli and Sparviero, plus Lampedusa at the quartile boundary level; 40\%) were shared between $\mathrm{BCC} 1$ and $\mathrm{BCC} 3$; and 14 islands (including Lampione, Montecristo, Cerboli, Sparviero; 87.5\%) were shared between BCC2 and BCC3. Among the islands included in the BCC1 p upper quartile, 10 (62.5\%, including Lampione, Montecristo, Lampedusa, La Scola, Cerboli and Sparviero) were shared with BCC1; 5 (33.3\%, including Lampione, Montecristo, Lampedusa, Cerboli and Sparviero) with BCC2, and 6 (40\%, including Lampione, Montecristo, Lampedusa, La Scola, Cerboli and Sparviero) with BCC3.

Two islands (Lampione and Montecristo) were recovered as high priority islands by all four BCC indices, and two (Cerboli and Sparviero) were at the borderline of the selected cut-off value. Islands falling in the higher third quartile varied significantly among the four indices for their area (ANOVA $\mathrm{F}=2.831, \mathrm{p}=0.047)$, perimeter $(\mathrm{F}=3.947$, $p=0.013)$, elevation $(F=5.984, p=0.001)$, but not for distance $(F=0.703, p=0.554)$. LSD tests revealed significant $(p<0.01)$ differences between BCC1 and all other indices for area, elevation, and perimeter, whereas differences among the other indices were not significant..

As regards the $\mathrm{BCW}$ indices, 11 islands (78.5\%) were shared in the highest third quartile between BCC1 and BCC2; 10 islands (71.4\%) were shared between BCC1 and BCC3; and 9 islands (64.3\%) were shared between BCC2 and $\mathrm{BCC} 3$. Among the islands included in the BCC1p upper quartile, $8(57.1 \%)$ were shared with BCC1; 4 (28.6\%) with BCC2, and $8(57.1 \%)$ with BCC3. Overall, Lampedusa, Lampione, Linosa, Marettimo, Pantelleria, and Ustica were recovered by all four indices; Capraia, Elba, Giglio, and Montecristo, by three indices.

Islands falling in the higher third quartile did not vary significantly among the four indices for their area (ANOVA $\mathrm{F}=0.688, \mathrm{p}=0.563)$, elevation $(\mathrm{F}=2.424, \mathrm{p}=0.076)$, distance $(\mathrm{F}=0.022, \mathrm{p}=0.996)$, or perimeter $(\mathrm{F}=1.113, \mathrm{p}$ $=0.352$ ).

\section{DISCUSSION}

The four BCC and BCW indices used in this study produced different island prioritisations, which may be explained by the different species rarity measures used to calculate them and the effect of island geography on species 
composition. The BCC1 highlighted the conservation importance of very remote, although faunistically poor, islands, a result also supported by the BCW1 index. These remote islands host few species as a consequence of their distance from possible source areas, yet these species have a narrow distribution, occurring on one or few islands. Moreover, as indicated by results achieved using BCC1p and $\mathrm{BCW} 1 \mathrm{p}$ indices, the faunas of these islands tend to be also characterised by species that are distributed on islands whose summed perimeter determines high rarity scores. This may appear surprising, because typically the most remote islands are those colonized by animal species with high dispersal power, which are also the most widely distributed among islands and which should have a total distribution with high perimeter. The fact that the most remote islands are usually colonised by widespread species is a common phenomenon and it is at the basis of the nested structure of most island faunas (Dennis et al. 2012; Ulrich et al. 2009). In the case of the tenebrionid beetles inhabiting the Italian small islands, two factors may have contributed to this unexpected pattern. First, tenebrionids tend to be sedentary animals, with low dispersal power, with most of the species found on small islands being flightless (Fattorini, 2002, 2008a, b, 2010a). This led to uncommon colonization events mostly favored by past land bridges and to repeated evolution of endemic forms (usually considered as subspecies), especially on the most isolated islands. Second, some of the most remote and highest priority islands are not exclusively sourced from the Italian peninsula and major islands but received several elements from the nearer North African mainland (Pantelleria, Linosa, Lampione and Lampedusa). Thus, these islands host several North African species that are absent from Italy and, hence, from all other islands. Interestingly, while BCC2 and BCC3 did not correlate with island distance, $\mathrm{BCW} 2$ and $\mathrm{BCW} 3$ were correlated with island isolation. This is consistent with the fact that endemic species, which have high conservation weights, tend to be more numerous on the most remote islands, thus increasing the BCW 2 and $\mathrm{BCW} 3$ values for remote islands.

Another important result is the negative relationships of BCC2 and BCC 3 with altitude, thus habitat diversity, which can be explained by the ecology of most of the tenebrionid species considered in this study. The BCC2 index included species' association with coastal environment as a factor of vulnerability in contrast with a broader habitat specificity. Although some low-elevation islands were occupied by forests before human exploitation (e.g. Lampedusa), in general, flat islands tend to be almost entirely occupied by coastal environments, and hence their faunal assemblages are mainly composed of tenebrionid species that were scored as rare for habitat because of their strict association with coastal environments. By contrast, islands with relatively higher elevations tend to be occupied also by non-coastal environments, such as the high Mediterranean maquis. The occurrence on these islands of tenebrionid species not strictly associated with coastal environments determines a decrease in the proportion of tenebrionids scored as rare for habitat in the BCC2 index, which led to a negative relationship between this index and island elevation.
The BCC3 index also had a negative correlation with island elevation. Because this index is based on a biogeographical categorization of species, this result implies that higher islands host species assemblages with a lower proportion of endemic species. This may be due to the fact that while endemic species are always a small number, a higher environmental diversity may promote the presence of many non-endemic species coming from the mainland. Because of the increase in the number of non-endemic species, endemics will represent a lower proportion of the tenebrionid faunas, thus leading to a decrease in the BCC3 index. Interestingly, BCW1 and BCW2 (constructed just to cope with potential over-indexing biases for poorest islands) were positively correlated with elevation. This indicates that the negative correlations found for BCC2 and BCC 3 may be due to the fact that environmentally more diverse islands may even have as many or more rare species than the lowelevation islands, but because they also have many common species in certain habitats, the average rarity is lower.

The BCC2 and BCC 3 results suggests that islands may be important not only for the presence of several endemic species, but also as ecological refugia for species associated with the particular coastal biotopes that have been deteriorated on more largely populated mainland areas. It should be also noted that $\mathrm{BCC}$ indices are not correlated with island area, whereas a positive correlation with island area was found for two $\mathrm{BCW}$ indices (BCW1 and BCW2). Lack of correlation with island area, however, is not a bias for the BCC index itself. For example, for the butterflies of the Italian islands the islands showing the highest $\mathrm{BCC}$ value were the largest in the sample (Dapporto \& Dennis, 2008).

The islands prioritised by the various indices varied significantly in their geographical characteristics. In particular, the set of islands recovered by the BCC1 index had mean geographical characteristics different from those of all other three BCC indices. By contrast, the four BCW indices recovered similar island sets that were not significantly different in their mean values for the geographical characteristics used in this study.

Although the various indices gave different island prioritisations, most of the islands included in the third quartile for two or more of the three indices belong to the same two archipelagos, the Tuscan Islands and the Pelagie Islands (plus two very isolated islands, Pantelleria and Ustica, which do not belong to any archipelago). Except the Aegadian islands of Marettimo (prioritised by BCW1, BCW2, BCW3) and Favignana (prioritised by BCW1 and $\mathrm{BCW} 2$, respectively), no island belonging to the other Italian archipelagos (Aeolian, Campane, Pontine, and Tremiti) was prioritised by more than one index.

In spite of their low levels of endemism, the islands of Ustica and Pantelleria have been prioritised by one (Ustica) and two (Pantelleria) BCC indices, and by all BCW indices. Despite Ustica and Pantelleria emerged recently, suggesting that there was not sufficient time for higher endemicity levels to develop, these islands are located quite far from Sicily and mainland areas. This characteristic could have favoured some relatively fast morphological differentiation in some tenebrionid populations. Actually, one endemic taxon (Opatrum validum marcuzzii) is known from Ustica 
(out of 26 taxa; 3.8\%) and two endemic taxa (Heliopathes avarus donatellae and Probaticus cossyrensis) from Pantelleria (out of $23 ; 8.7 \%$ ). Only a fraction of the surface of these two islands is protected. The "Riserva naturale orientata Isola di Ustica" covers 204.36 hectares, i.e. $23.76 \%$ of Ustica's area, whereas the "Riserva naturale orientata Isola di Pantelleria" occupies an area of 2626.69 hectares, i.e. about $30 \%$ of the island's area. However, in both islands there is some habitat variability represented by presence of coastal areas, pine woods and maquis. Pantelleria in particular hosts a great mosaic of environmental variability including the Venere lake area, different woods around the Montagna Grande area and traditionally managed agricultural areas.

The Pelagie Islands are remote and very ancient islands. The island of Lampedusa (the largest amongst the Pelagie) shows a relatively rich tenebrionid fauna, including 28 taxa, 4 of which (Erodius audouini destefanii, Pachychila dejeani doderoi, Alphasida puncticollis tirellii, Asida minima; 14.3\%) are endemic to this island. This island was included in the third quartile by both BCC1 and BCC2. Lampione, an islet of just $0.03 \mathrm{~km}^{2}$, hosts six tenebrionid taxa, three of which (Alphasida puncticollis moltonii, Tentyria n. sp. and Opatrum validum rottembergi) are endemic to this island, and one (Machlopsis doderoi), endemic to the Pelagie Islands, occurs on Lampedusa and Lampione. Nineteen species are known from Linosa, with no exclusive endemic (although it is not clear if the Tentyria population of this island belongs to an African species or it is an endemic species), but Stenosis brignonei is endemic to Linosa and Lampedusa, and Linosa was included in the first quartile by the $\mathrm{BCC} 1$ index and the $\mathrm{BCC} 1 \mathrm{p}$ index as well as by all $\mathrm{BCW}$ indices. The "Riserva naturale orientata Isola di Lampedusa" covers 369.68 hectares, i.e. about 15\% of the island's area. The "Riserva naturale orientata/integrale Isola di Linosa e Lampione" (266.87 hectares) covers about $49.5 \%$ of Linosa (as an oriented nature reserve) and $100 \%$ of Lampione (as a strict nature reserve).

As a whole, Pantelleria and the Pelagie Islands host several species, more or less widely distributed in North Africa (especially Algeria and Tunisia), which occur in Europe only on these islands, like Imatismus villosus and Pseudoseriscius griseovestis on Linosa; Pachychila crassicollis cossyrensis and Opatrum validum schlicki on Pantelleria; Pachychila tazmaltensis, Eutagenia aegyptiaca tunisea and Microtelus lethierryi on Lampedusa; Allophylax costatipennis costatipennis on Lampedusa and Linosa; Gonocephalum perplexum on Lampedusa and Pantelleria. Thus, although Pantelleria and the Pelagie islands host few species, as expected because of their very small area and high isolation, their tenebrionid faunas are very peculiar, which leads to a high prioritisation.

All other islands selected by one or more indices belong to the Tuscan Archipelago. The Tuscan Archipelago is composed of seven main islands (Elba, Giglio, Capraia, Pianosa, Montecristo, Gorgona and Giannutri) and several islets located in the Tyrrhenian Sea, between Corsica and the Italian Peninsula. Main islands range from $2.2 \mathrm{~km}^{2}$ (Gorgona) to $223.5 \mathrm{~km}^{2}$ (Elba). The islands differ considerably in terms of their origin and geological features. The island of Gorgona is composed by both sedimentary and ophiolitic rocks. The island of Capraia is volcanic and originated about nine million years ago. The island of Montecristo is entirely granite, as is most of the Island of Giglio. The island of Elba shows a more composite origin, being granite in the western part (where Mount Capanne reaches 1018 m elevation), sedimentary and metamorphic in the central and eastern part (with gneiss and marble rocks) and alluvial (with clay, sandstone, and limestone soils) in the central plains. The island of Pianosa is composed of sedimentary rocks and shell formations. A total of 59 native taxa are known from these islands, 13 of which $(22 \%)$ are endemic. Out of these 13 endemics, one (Asida gestroi) is classified as species, the others being represented by populations classified as subspecies. The percentage of endemic taxa (single island endemics and taxa endemic to the archipelago) varies considerably among the main islands, ranging from $5.88 \%$ (Elba, with two endemic taxa out of 34 taxa) to $55.56 \%$ (Montecristo, with 5 endemic taxa out of 9 taxa), whereas the islets have higher levels of endemism (67-100\%) but with very few species (1-3 taxa). This is due to the fact that islets are colonised from adjacent islands by taxa that are endemic to the archipelago, but which are widespread within it. It has been suggested that for animals with low mobility (Fattorini, 2010a), islets tend to be colonized by adjacent islands more than by mainland areas, and this is probably the case of the islets surrounding the islands in the Tuscan Archipelago, such as the very small rocks around Elba island.

Levels of endemism can be explained by the paleogeographical history of this archipelago, with the islands which were isolated for longer showing higher levels of endemism (Fattorini, 2009a, b). Most endemics are associated with garrigue and maquis biotopes. Some taxa show an impressive cladogenesis, being represented with populations endemic to individual islands or to groups of a few islands, such as Asida luigionii (with two subspecies, doriai and insularis), the endemic A. gestroi (with the subspecies gestroi, tyrrhena, capraiensis, lanzai, and gardinii), and Opatrum sculpturatum (with the endemic subspecies ilvense, urgonense, capraiense and igiliense). The only endemic taxa likely associated with woodlands are Colpotus strigosus oglasensis and Odocnemis ruffoi osellai.

All islands of the Tuscan Archipelago are part of a National Park and most of their environmentally valuable areas are under strict protection. In particular all the entire island of Montecristo represents a biogenetic reserve established in 1971. Only two peoples live there, both nature reserve keepers. Visitors are highly restricted in yearly number and activities. Also on Gorgona and Pianosa access is regulated, but other islands were subject to high tourism pressures, notably Elba and Giglio. Despite the human population on the Tuscan Islands is relatively small and declining (e.g., de Fabrizio, 2005), there have been important anthropic influences. Serious consequences have been produced by past growth of mass tourism (and partly also of the so-called ecotourism). This has resulted in the rapid degradation of the most fragile natural habitats especially before the establishment of the National Park. The effects have been especially serious on the coastal environments, which became more and more attractive to tourists just because of their increasing rarity. This is the case of the few and scattered sandy shores on Giglio, now completely obliterated 
by bathing establishments, or, of the small and very isolated beaches, constantly visited by tourists. The psammophilous species Phaleria spp. and Trachyscelis aphodioides are now considered to be extinct on this island as a result of the high anthropic pressure on the beaches. Increasing rarity of wellpreserved places led to high pressure from tourists also on the Island of Giannutri. Although most of the footways on this island are currently forbidden, this is not known by most tourists, who reach the island by ferry-boats and concentrate in the few accessible places.

\section{CONCLUSIONS}

Most of the studied islands have been recovered as having some conservation value according to their tenebrionid faunas. No island was found to have a BCC value of zero with BCC1, only one with BCC2 and a few with BCC3. This fits with the high tendency for tenebrionids to have relict populations or to form endemic species and races resulting in virtually all the islands and islets to be considered of some conservation interest. Insular phenomena are know in many other organisms from Italian islands and this resulted in most islands being identified as Natura 2000 sites (see references reported in Table 2). Many islands are also part of National Parks or other types of protected areas at national or regional level. Therefore, virtually all islands are formally regarded as areas of conservation concerns. However, a formal recognition does not automatically imply that concrete measures for conservation are adopted. Because of limitation of funds and the need of urgent actions for the most "valuable" areas, prioritisation may help to allocate founds or enhance concrete conservation actions and appropriate integrated management policies in selected areas. The use of integrated management policies are extremely important in the context of the Italian small islands, because most of them are inhabited and/or used by people and it is necessary to avoid an opposition between economics and environmental sustainability. Results of our analyses of tenebrionid beetles indicate some islands as having highest priorities, which does not mean that other islands are of scarce interest. These include the islands belonging to the Tuscan Archipelago and some Sicilian Islands (Pelagie, Pantelleria and Ustica). Whereas the islands belonging to the Tuscan Archipelago are part of a National Park, Pantelleria, Ustica and the Pelagie Islands are both classified as natural reserves, not as a National park, and one of them (Lampedusa) is under severe anthropic pressure and social contrasts as it is a primary European entry point for migrants, mainly coming from Africa. More attention at national level should be paid in such situation.

\section{ACKNOWLEDGMENTS}

We would like to acknowledge P. Cardoso, P. Lo Cascio and G. Gardini for their suggestions and corrections.

\section{REFERENCES}

Aliquò, V.; Rastelli, M.; Rastelli, S.; Soldati, F. (2006) Coleotteri Tenebrionidi d'Italia. CD-ROM. Museo Civico di Storia Naturale di Carmagnola, Carmagnola, Italy. ISBN: 8890120185.
Arnold, C. (2008) - Mediterranean Islands. 416p., Survival Books, London, U.K. ISBN: 978-0955648915.

Bergerot, B.; Lasne, E.; Vigneron, T.; Laffaille, P. (2008) - Prioritization of fish assemblages with a view to conservation and restoration on a large scale European basin the Loire (France). Biodiversity and Conservation, 17(9):2247-2262. DOI: 10.1007/s10531-008-9331-6.

Dapporto, L.; Dennis, R.L.H. (2008) - Island size is not the only consideration. Ranking priorities for the conservation of butterflies on Italian offshore islands. Journal of Insect Conservation, 12(3-4):237-249. DOI: 10.1007/s10841-008-9150-9.

De Fabrizio, E. (2005) - Isola del Giglio. Il territorio, gli abitanti e la storia. 272 p., Proloco dell'Isola del Giglio, Grosseto, Italy.

Dennis, R.L.H.; Dapporto, L.; Shreeve, T.G.; John, E.; Coutsis, J.G.; Kudrna, O.; Saarinen, K.; Ryrholm, N.; Williams, W. R. (2008) - Butterflies of European islands: the implications of the geography and ecology of rarity and endemicity for conservation. Journal of Insect Conservation, 12(3-4):205-236. DOI: 10.1007/s10841008-9148-3.

Dennis, R.L.H.; Hardy, P.B.; Dapporto, L. (2012) Nestedness in island faunas: novel insights into island biogeography through butterfly community profiles of colonization ability and migration capacity. Journal of Biogeography, 39(8):1412-1426. DOI: $10.1111 /$ j.13652699.2012.02698.x.

Dias, J.A.; Carmo, J.A. do; Polette, M. (2010) - Breves considerações sobre as ilhas e a sua gestão. Revista de Gestão Costeira Integrada / Journal of Integrated Coastal Zone Management, 10(3):243-253. DOI: 10.5894/rgci237

Fattorini, S. (2002) - A comparison of relict versus dynamic models for tenebrionid beetles of Aegean Islands (Greece) (Coleoptera: Tenebrionidae). Belgian Journal of Zoology, 132(1):55-64. Available at: http://www.naturalsciences. be/institute/associations/rbzs_website/bjz/back/pdf/BJZ 132 (1)/Volume 132(1), pp. 55-64.pdf

Fattorini, S. (2006a) - Biogeography and conservation of endemic tenebrionid beetles (Coleoptera Tenebrionidae) on East Mediterranean islands. Vie et Milieu, 56:231-241. Available at: http://www.obs-banyuls.fr/Viemilieu/index. php/volume-56-2006/56-issue-3/563-article-4.html

Fattorini, S. (2006b) - A new method to identify important conservation areas applied to the butterflies of the Aegean Islands (Greece). Animal Conservation, 9(1):75-83. DOI: 10.1111/j.1469-1795.2005.00009.x.

Fattorini, S. (2008a) - Ecology and conservation of tenebrionid beetles in Mediterranean coastal areas. In: Fattorini, S. (ed.), Insect Ecology and Conservation, pp. 165-297. Research Signpost, Trivandrum, Kerala, India. ISBN: 978-8130802978.

Fattorini, S. (2008b) - A multidimensional characterization of rarity applied to the Aegean tenebrionid beetles (ColeopteraTenebrionidae). JournalofInsect Conservation, 12(3-4):251-263. DOI: 10.1007/s10841-007-9080-y.

Fattorini, S. (2009a) - Both Recent and Pleistocene geography determines animal distributional patterns in the Tuscan Archipelago. Journal of Zoology, 277(4):291301. DOI: 10.1111/j.1469-7998.2008.00540.x. 
Fattorini, S. (2009b) - Faunal patterns in tenebrionids (Coleoptera: Tenebrionidae) on the Tuscan Islands: The dominance of paleogeography over recent geography. European Journal of Entomology, 106(3):415-423. DOI: 10.14411/eje.2009.053.

Fattorini, S. (2010a) - The influence of geographical and ecological factors on island beta diversity patterns. Journal of Biogeography, 37(6):1061-1070. DOI: 10.1111/j.1365-2699.2009.02252.x.

Fattorini, S. (2010b) - Use of insect rarity for biotope prioritisation: the tenebrionid beetles of the Central Apennines (Italy). Journal of Insect Conservation, 14(4):367-378. DOI: 10.1007/s10841-010-9266-6.

Fattorini, S. (2010c) - Biotope prioritisation in the Central Apennines (Italy): species rarity and cross-taxon congruence. Biodiversity and Conservation, 19(12):34133429. DOI: $10.1007 / \mathrm{s} 10531-010-9903-0$.

Fattorini, S. (2011a) - Biogeography of tenebrionid beetles (Coleoptera: Tenebrionidae) in the circum-Sicilian islands (Italy, Sicily): Multiple biogeographical patterns require multiple explanations. European Journal of Entomology, 108(4):659-672. DOI: 10.14411/eje.2011.084.

Fattorini, S. (2011b) - Influence of island geography, age and landscape on species composition in different animal groups. Journal of Biogeography, 38(7):1318-1329. DOI: 10.1111/j.1365-2699.2011.02486.x.

Fattorini, S. (2013a) - Species ecological preferences predict extinction risk in urban tenebrionid beetle guilds. Animal Biology, 63:93-106. DOI: 10.1163/1570756300002396.

Fattorini, S. (2013b) - Relations between species rarity, vulnerability, and range contraction for a beetle group in a densely populated region within the Mediterranean biodiversity hotspot. Conservation Biology, 28(1):169176. DOI: 10.1111/cobi.12157.

Fattorini, S.; Fowles, A. (2005) - A biogeographical analysis of the tenebrionid beetles (Coleoptera, Tenebrionidae) of the island of Thasos in the context of the Aegean Islands (Greece). Journal of Natural History, 39 (46), 3919-3949. DOI: $10.1080 / 00222930500533443$.

Fattorini, S.; Santoro, R.; Maurizi, E.; Acosta, A.T.R.; Di Giulio, A. (2012a) - Environmental tuning of an insect ensemble: the tenebrionid beetles inhabiting a Mediterranean coastal dune zonation. Comptes rendus Biologies, 335(10-11):708-711. DOI: 10.1016/j. crvi.2012.09.009.
Fattorini, S.; Cardoso, P.; Rigal, F; Borges, P.V.A. (2012b) Use of Arthropod Rarity for Area Prioritisation: Insights from the Azorean Islands. PLoS ONE, 7(3):e33995. DOI: 10.1371 /journal.pone.0033995.

Kattan, G. (1992) - Rarity and vulnerability: the birds of the Cordillera Central of Colombia. Conservation Biology, 6(1):64-70. DOI: 10.1046/j.15231739.1992.610064.x.

Laffaille, P.; Chantepie, S.; Lasne, E. (2011) - Assessing the conservation value of waterbodies: the example of the Loire floodplain (France). Biodiversity and Conservation, 20(11):2427-2444. DOI: 10.1007/s10531-0119994-2.

Löbl, I.; Smetana, A. (eds) (2008) - Catalogue of Palaearctic Coleoptera. Vol. 5. Tenebrionoidea. 670p., Apollo Books, Stenstrup, Aamosen, Denmark. ISBN: 9788788757699.

Maire, A.; Buisson, L.; Biau, S.; Canal, J.; Lafaille, P. (2013)A multi-faceted framework of diversity for prioritizing the conservation of fish assemblages. Ecological Indicators, 34:450-459. DOI: 10.1016/j.ecolind.2013.06.009.

Manne, L. (2013) - Island species with nowhere to go. In: J. F. Brodie, E. Post \& D. F. Doak (eds.), Wildlife conservation in a changing climate, pp. 226-244, The University of Chicago Press, Chicago, IL, U.S.A. ISBN: 978-0226074634.

Morey, M.; Martínez-Taberner, A. (2000) - Environmental conservancy strategies in the Mediterranean islands. In: Trabaud L. (ed.), Life and Environment in the Mediterranean, pp. 345-386, Wit-Press, Southampton, U.K. ISBN: 978-1853126802.

Saffache, P..; Angelelli, P. (2010) - Integrated Coastal Zone Management in small islands: A comparative outline of some islands of the Lesser Antilles. Revista de Gestão Costeira Integrada / Journal of Integrated Coastal Zone Management 10(3):255-279. DOI: $10.5894 / \mathrm{rgci} 228$

Ulrich, W.; Almeida, M.; Gotelli, N.J. (2009) - A consumer's guide to nestedness analysis. Oikos, 118(1):3-17. DOI: 10.1111/j.1600-0706.2008.17053.x.

Whittaker, R.J.; Fernández-Palacios, J.M. (2007) - Island biogeography: ecology, evolution, and conservation. 2nd edn., 416 p., Oxford University Press, Oxford \& New York. ISBN: 978-0198566120. 